\title{
TEST AND RESEARCH FOR KEY TECHNOLOGY OF CAST-IN-PLACE PILE CONSTRUCTION IN THE AREA OF SILT-ROCK FILL LAYER
}

\author{
Shengliang $\mathrm{Lu}^{1,2^{*}}$, Jie Zhang ${ }^{1}$, Hongxing $\mathrm{X} \mathrm{u}^{3}$, Yu Zhang ${ }^{4}$ \\ ${ }^{1}$ College of Engineering, Shantou University, Shantou, Guangdong, 515000, China; \\ ${ }^{2}$ Department of architectural engineering, Wenzhou Vocational \& Technical College, Wenzhou, 325000, China; \\ ${ }^{3}$ Infrastructure construction department, Wenzhou Medical University, Wenzhou, Zhejiang, 325000, China; \\ ${ }^{4}$ Department of hydraulic engineering, Dalian University of Technology, Liaoning, Dalian, 116000, China \\ lushengl84@yeah.net
}

\begin{abstract}
Taking the cast-in-place pile construction project in the new campus of a University that locates in an area with silt-rock fill soil as an example, 15 cast-in-place piles were constructed using five drilling schemes and tested using full-scale tests. Data were recorded in the process of the test. The results were detected using acoustic transmission method and vertical compression static load test. Taking engineering experience into account, percussion drill method was considered as the most suitable for the construction of cast-in-place piles in areas with silt-rock fill soil. Then in-situ full-scale test of burial depth of steel casing were carried out on 21 piles which were constructed using percussion drill method and divided into 3 groups. The optimal burial depth of steel casing and the limitations of mud protection wall in rock-fill and silt soil were obtained according to the construct cost of one pile, construction period and filling coefficient. Based on the above achievements, a set of effective, high-efficient, reliable, economic and environmental-friendly construction technique was proposed and applied in the construction of 3867 cast-in-place piles in the campus. The construction indicators and actual result were satisfactory. The results can offer a reference for the construction of cast-in-place piles in areas with silt-rock fill soil.
\end{abstract}

Keywords: Silt-Rock Fill Layer, Cast-In-Place Pile, Construction Technology, In-Situ Test.

\section{Introduction}

With the high-speed development of urban construction, urban construction land has been increasingly less. Many coastal cities tend to fill up the sea in shallow areas to satisfy the demands of port construction and other urban construction land [1]. The typical soil layer formed after sea reclamation, i.e. silt-rock fill layer, is what this study investigated. Cast-in-place pile [2] has been extensively applied in the construction based on such a kind of soil layer for its high adaptability to various stratum conditions, flexibility in diameter and length and capability of satisfying different requirements on bearing capacity [3-5].

Cast-in-place piles have been used as the foundation in Qingdao Kiaochow Bay, Hangzhou Bay, Wenzhou Oufei Project and Shenzhen Nanshan District which locate in the areas with silt-rock fill soil. But pile forming is difficult and the waste pile rate is also high because of the problems such as deviation in the position of pile hole and the diameter of pile, deflection of pile hole, local hole wall protrusion, difficult penetration of rock-fill layer and collapse of hole wall $[3,5,8]$. As silt-rock fill layer is caused by sea reclamation which is implemented in recent years, engineers have not fully understood the pile forming mechanism and construction techniques of cast-in-place piles, there is no unified scheme for construction of cast-in-place piles, and technical descriptions for regulations [2] are also lack of, which is bound to affect the reasonable design, accurate estimation of cost and construction process. In recent years, some scholars and staffs in China and abroad have made some beneficial exploration in this aspect. Lei and Xia [3] proposed to trip in deep and long steel casings with vibratory hammer in the upper rock-fill section, grasp using percussion and grabbing hammer if encountering the rock-fill layer and create pores using rotary drilling machine in the stratum below steel casings. Zhao W et al. [4] has solved the problem of difficult pile foundation construction with rotary drilling rig in complex stratum in coastal regions by controlling key technologies. In the studies of Zhang [9] and Zomora [10], the relationships between slurry performance indicator of cast-in-place piles, mechanism of slurry protection and stability of hole walls was analyzed. Donald E. Gerken et al. [5] carried out in-situ mechanical test after the construction of cast-inplace pile foundation and investigated the transfer mechanism of bearing capacity based on data. Overall, study on how to fulfil the construction of cast-in-place piles in the silt-rock fill layer is not enough. The previous studies mainly focused on how to successfully complete the construction of cast-inplace pile foundation in specific projects, but seldom 
investigated the universal rules in the aspects of comprehensive indicators such as construction cost and period and environmental protection; as a result, the diversified schemes and complex procedures led to low efficiency $[6,7]$. In the previous studies, there were many qualitative conclusions, and moreover most of them concentrated on some specific procedure rather than the feasibility of schemes in the aspects of the overall construction techniques and systematicness of castin-place piles which are the keys in pile forming. Thus the theoretical study far lags behind the engineering practice.

The authors of this study made a large amount of full-scale tests taking a key project in Zhejiang province as an example and proposed a set of effective, high-efficient, reliable, economic and environmental friendly construction techniques based on the test data and engineering experience to offer to a reference for the construction of cast-inplace pile construction in areas with silt-rock fill soil.

\section{Project Profile and Geological Condition}

A new campus of a university which covers a site area of $343498.4 \mathrm{~m}^{2}$ and a building area of 316707.4 $\mathrm{m}^{2}$ is a key project of Zhejiang province in China. Buildings planned to be built include dormitory building, teachers' apartment, teaching building, school administrative room, laboratory building, library, dining hall and storm-proof playground. The buildings have 3 to 10 layers and are $15.9 \sim 39.8 \mathrm{~m}$ high. All the buildings adopt frame-shear wall, and there are four sections.
The engineering site is located in an island in the coastal region of China. To the east is the urban area, to the south is the mountains, and to the west and north is the sea. Geological survey includes initial survey stage and detailed survey stage, and drilling, in-site test and indoor soil test are combined together. The initial water level was $0.40 \sim 2.50 \mathrm{~m}$ deep, and the stable water level was $0.30 \sim 2.30 \mathrm{~m}$ deep. The water was mainly composed of porephreatic water reserved in the superficial part and pore-confined water reserved in the middle and lower part of the detritus soil. The site was superficially covered by soft silt soil with an average thickness of $15 \mathrm{~m}$ and poor properties. The soil was gray and plastic and featured by high water content, large air space ratio, strong compressibility and high risks of disturbance deformation. Moreover it contained some shell debris and silt block mass. The middle layer of the site was mainly composed of cohesive soil with moderate compressibility and mechanical property between general level and high level. The lower layer was composed of strongly weathered and moderately weathered quartz syenite porphyry which had favourable mechanical property and located $60 \sim 80 \mathrm{~m}$ under the surface. The physical-mechanical property indicators of the soil are shown in Table 1.

The site was levelled by means of slag backfill 13 months before construction. The backfill material with a loose structure was mainly composed of rock blocks, rubbles and gravels. The size of the rock blocks was generally between 0.20 and $0.70 \mathrm{n}$, and the maximum could be larger than $1.50 \mathrm{~m}$. The thickness of backfill was between $6.50 \mathrm{~m}$ and $15.8 \mathrm{~m}$. The schematic diagram of the soil layer in the site is shown in Figure 1, and the site after backfill is shown in Figure 2.

\begin{tabular}{|l|l|c|c|c|c|c|}
\hline & $\begin{array}{l}\text { Moisture } \\
\text { content (\%) }\end{array}$ & $\begin{array}{l}\text { Natural unit } \\
\text { weight KN/m3 }\end{array}$ & $\begin{array}{l}\text { Pore } \\
\text { space } \\
\text { ratio e }\end{array}$ & $\begin{array}{l}\text { Plasticity } \\
\text { index Ip }\end{array}$ & $\begin{array}{l}\text { Liquidity } \\
\text { index IL }\end{array}$ & $\begin{array}{l}\text { Compressio } \\
\text { n coefficient } \\
\text { MPa-1 }\end{array}$ \\
\hline Silt & 61.7 & 16.3 & 1.747 & 25 & 1.46 & 1.64 \\
\hline Silty clay & 32.7 & 18.7 & 0.941 & 16.4 & 0.58 & 0.36 \\
\hline Silt & 38.8 & 18.2 & 1.098 & 19 & 0.76 & 0.56 \\
\hline Silt & 30.9 & 19 & 0.888 & 17.6 & 0.48 & 0.29 \\
\hline Silt & 36.5 & 18.5 & 1.018 & 18.9 & 0.69 & 0.42 \\
\hline $\begin{array}{l}\text { Angular gravel } \\
\text { containing cohesive soil }\end{array}$ & & & & & & \\
\hline Silt & 31.3 & 19.3 & 0.88 & 19.3 & 0.39 & 0.32 \\
\hline Silt & 39.0 & 18.1 & 1.121 & 21.4 & 0.75 & 0.54 \\
\hline $\begin{array}{l}\text { Angular gravel } \\
\text { containing cohesive soil }\end{array}$ & 26.6 & & & & & \\
\hline Silty clay & 42.1 & 19.6 & 0.768 & 14.1 & 0.43 & 0.25 \\
\hline Silt & 23.8 & 19.9 & 0.649 & 12.1 & 0.51 & 0.25 \\
\hline $\begin{array}{l}\text { Silty clay containing } \\
\text { rubbles }\end{array}$ & & & & & \\
\hline $\begin{array}{l}\text { Strongly weathered quartz syenite } \\
\text { porphyry }\end{array}$ & & & & & \\
\hline $\begin{array}{l}\text { Moderately weathered quartz syenite } \\
\text { porphyry }\end{array}$ & & & & & \\
\hline
\end{tabular}


All the engineering piles were compressive piles.

The design of the pile foundation was grade II. Reinforced concrete filling piles were used.

The strength of pile shaft concrete was C40.

The diameter of piles was about $800 \mathrm{~mm}$.

The main reinforcement of reinforcement cage had a path length of $12 \varphi 25$.

The thickness of the protection layer of longitudinal bars was $55 \mathrm{~mm}$.

The minimum effective pile length was $70 \mathrm{~m}$, and at least $2400 \mathrm{~mm}$ of the full cross section of pile tip entered the bearing stratum.

The thickness of sediment was not larger than 50 $\mathrm{mm}$.

The bearing stratum of pile foundation was composed of moderately weathered quartz syenite porphyry. The characteristic value $\mathrm{Ra}$ of vertical compressive bearing capacity of single pile was required as $3100 \mathrm{kN}$.

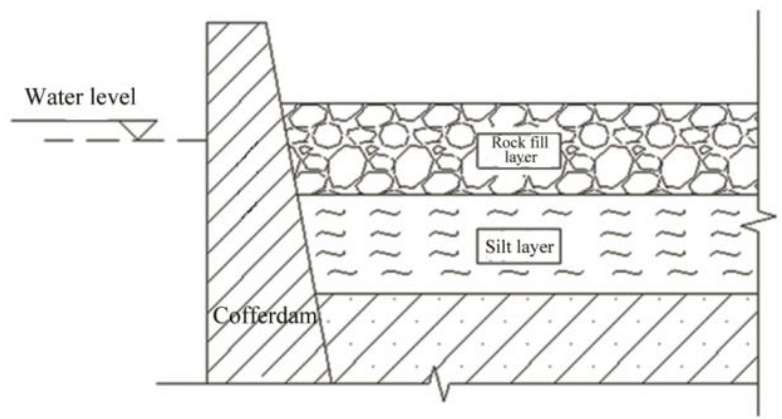

Figure 1: Silt-rock fill layer

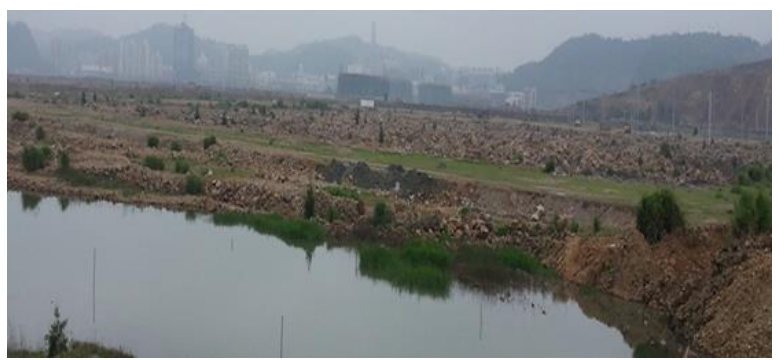

Figure 2: Backfill site

\section{Design of Drilling Construction Test}

\subsection{Experimental design for technological process}

The construction technological process of the cast-in-place piles is shown in Figure 3. The quality control standards of the technological step followed relevant regulations [1].

The special technical parameters and requirements are shown in Figure 3.

The wall of the steel casings was $8 \mathrm{~mm}$ thick, 900 $\mathrm{mm}$ wide and $2.0 \mathrm{~m}$ long. The steel casings were buried using an excavator. The opening of each casing was $300 \mathrm{~mm}$ above the ground. The bottom and its surrounding were filled with clay and tamped layer by layer.
To ensure its stability, the deviation of the centre of the casing and the centre of pile position was not larger than $50 \mathrm{~mm}$.

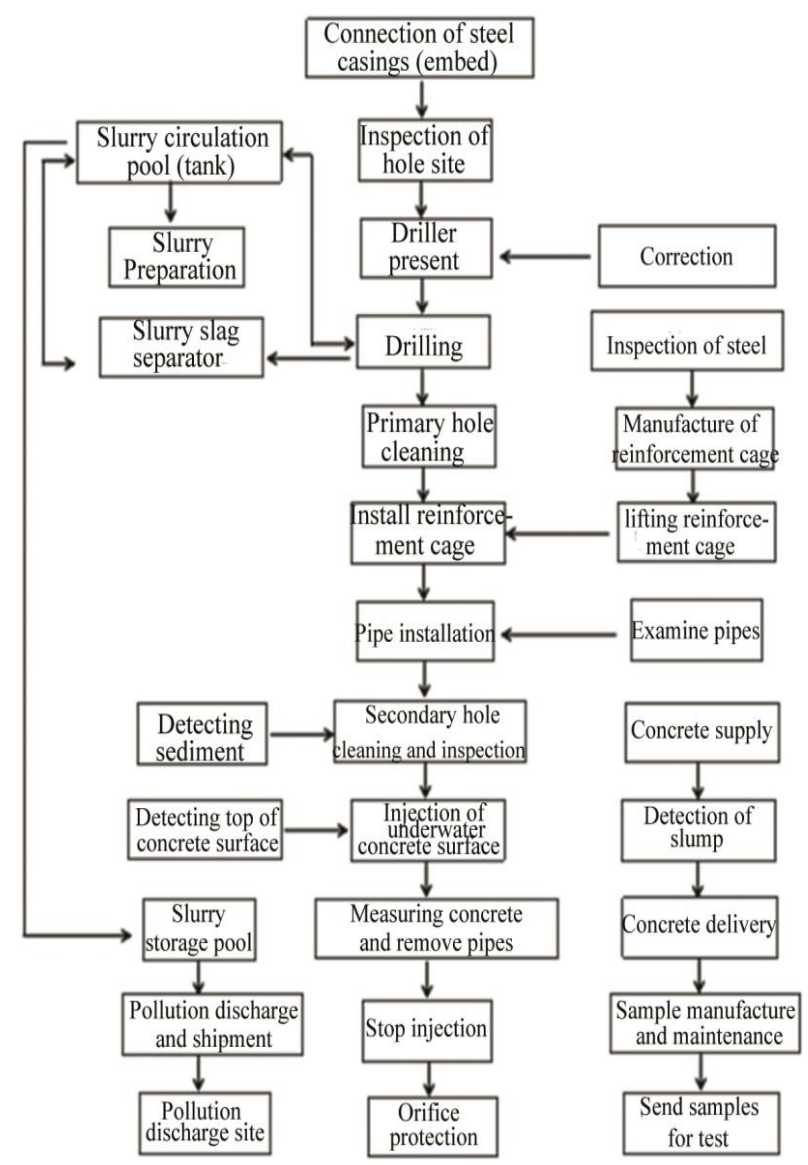

Figure 3: Technological process

To prevent the flow of the silt layer, the burying of the casings should start after pile foundation concrete placement.

The original soil was added with high-quality bentonite and chemical additive $\mathrm{NaOH}$ to produce artificial slurry. The slurry was fully stirred using a drilling machine to improve the indicators of the slurry. The relative density of slurry was $1.3 \sim 1.4$ in the rock-fill layer and $1.2 \sim 1.25$ in the silt and clay layers. The viscosity of the slurry was not lower than $20 \mathrm{~s}$, the sand content was not higher than $4 \%$, and the colloid fraction was not lower than $2.5 \mathrm{~L} / \mathrm{kg}$. The slurry density was detected every other hour by special staffs.

The holes were cleaned by pump-suction reverse circulation. To prevent hole collapse in the silt-rock fill layer during drilling, the relative density of the slurry should be kept at not lower than 1.20 in the primary hole cleaning, excessively rapid dilution should be avoided, and 1 hour was the suitable duration of the primary hole cleaning. In the secondary hole cleaning, the relative density of slurry was $1.15 \sim 1.2$, the viscosity was not larger than $28 \mathrm{~s}$, the sand content was not larger than 4\%, and the thickness of hole bottom's grit was not larger than $50 \mathrm{~mm}$. 
Reinforcement cage was manufactured in two parts. The major reinforcements were connected using direct thread sleeves. After the crawling crane put the reinforcement down, the crawling cranes were jointed using single-side welding in site.

Underwater concretes were poured using $\varphi 30$ $\mathrm{cm}$ pipe. The slump was between $180 \mathrm{~mm}$ and 220 $\mathrm{m}$, and the diffusivity was between $350 \mathrm{~mm}$ and 440 $\mathrm{mm}$. When the casting concrete passed the silt layer, the filling coefficient was large and unstable. To prevent pile breaking when the lower end of the pipe away from the concrete surface, the position of the concrete surface in the hole was firstly probed using measuring ropes before pipe lifting, and then the buried depth of the pipes should be adjusted according to the actual position of the concrete surface.

\subsection{Experimental design for drilling scheme}

Five construction schemes were designed for drilling process according to the geographical survey report and design requirements and based on practical engineering experience. Fifteen cast-inplace piles were constructed based on in-situ fullsize test, rotary excavating method for pile $1 \# \sim 3 \#$, replacement-filling rotary excavating method for pile $4 \# \sim 6 \#$, churn drilling method for pile $7 \# \sim 9 \#$, punching method 1 for pile $10 \# \sim 12 \#$, and punching method 2 for pile 13\# 15\#. The detailed descriptions of every drilling scheme are shown in Table 2. At least give steel plates were prepared for every construction machine during drilling to prevent the disturbance influence of machinery waggle on soil.

\begin{tabular}{|c|c|}
\hline & Dol \\
\hline Name of scheme & Details \\
\hline Rotary excavating & $\begin{array}{l}\text { A GW-30 engineering driller drilled holes, with reverse circulation of roller } \\
\text { cutter bits. The penetration speed was controlled at } 5 \mathrm{~m} / \mathrm{h} \text {, and the walls } \\
\text { were protected by slurry. }\end{array}$ \\
\hline $\begin{array}{l}\text { Replacement-filling rotary } \\
\text { excavating }\end{array}$ & $\begin{array}{l}\text { The rock-fill layer which was } 3 \mathrm{~m} \text { around the piles was excavated and } \\
\text { carried away from the construction site. Then it was filled by cohesive soil } \\
\text { and tamped. Finally holes were created using rotary excavating method. }\end{array}$ \\
\hline Churn drilling & $\begin{array}{l}\text { The rock-fill layer was drilled using ZJC simple percussion drill. The stroke } \\
\text { length was controlled between } 1 \text { and } 1.5 \mathrm{~m} \text {. The weight of the hammer was } \\
\text { 2T. With the walls protected by slurry, holes in the silt layer were created } \\
\text { using rotary excavating. }\end{array}$ \\
\hline Punching method 1 & $\begin{array}{l}\text { The soil layer was drilled using a ZJC simple percussion drill. The stroke } \\
\text { length of the rock-fill layer was controlled between } 1 \mathrm{~m} \text { and } 1.5 \mathrm{~m} \text {. The } \\
\text { stroke length of the silt layer was controlled between } 1.5 \mathrm{~mm} \text { and } 2 \mathrm{~m} \text {. The } \\
\text { stroke length of other layers was controlled between } 2 \mathrm{~m} \text { and } 2.5 \mathrm{~mm} \text {. The } \\
\text { weight of the hammer was } 2 \mathrm{~T} \text {. The walls were protected by slurry. }\end{array}$ \\
\hline Punching method 2 & $\begin{array}{l}\text { This scheme was the same with punching method } 1 \text {. But } 8 \mathrm{~mm} \text {-thick steel } \\
\text { casings were used in the silt-rock fill layer. It was tripped in using single use } \\
\text { of vibratory hammer. Walls in other soil layers were also protected by } \\
\text { slurry. The parameters were the same with the rotary excavating method. }\end{array}$ \\
\hline
\end{tabular}

\subsection{Design of detection}

Besides conventional indicators such as typeselection of equipment, drilling parameter, construction period, construction cost and construction difficulties, data such as the curve of variation of the filling coefficient with the changes of pouring depth, curve of load settlement and pile shaft completeness indicator were also needed. The detection method was designed as follows.

The floating ball on one end of the measuring rope was put into the pile. The floating ball went up with the rise of the concrete surface. Then the scale height $h$ of the concrete surface was measured. The concrete placement volume between $70 \mathrm{~m}$ under the horizontal plane and the ground corresponding to $h$ was measured. The finished concrete placement volume Vactual corresponding to $\mathrm{h}$ was calculated according to reality. But the waste quantity of concrete caused by improper construction management was not included in $V_{\text {actual }}$. The theoretical concrete placement volume was calculated using equation (1). The filling coefficient was defined as: $\mathbf{c}=\mathrm{v}_{\text {actual }} / \mathrm{v}_{\text {theoreticd }}$.

$$
V_{\text {theoretical }}=1 / 4 \pi d^{2}\left(l+h_{1}\right)
$$

where $V_{\text {theoreticd }}$ stands for the theoretical concrete placement volume, $d$ stands for the diameter of pile shaft, $l$ sands for the length of pile shaft, and $h_{1}$ stands for the height of over filling.

The load and settlement curve was obtained from single pile vertical compressive static load test [8]. Slow maintenance loading method was used. The maximum load $\mathrm{Q}_{\max }$ was $2 \mathrm{Ra}$, i.e. $6200 \mathrm{kN}$. Load was loaded using an electric oil pump in ten grades and unloaded to 0 in 5 grades. 
The loading system is shown in Figure 4. The settlement displacement $\mathrm{s}$ of pile top was measured using a displacement sensor which was fixed on the datum line beam with a magnetic stand and symmetrically placed at the top of pile. Loading pressure and displacement observation were displayed and recorded using a RS-JYB static load tester (Wuhan Yanhai Engineering Technology Development Co., Ltd., China). Observation time $t$ was read every 15 min after every grade of loading and read every $30 \mathrm{~min}$ one hour later. Due to the limited space, the unaccomplished matter and result evaluation criteria were not described here, and could refer to relevant regulations [8].

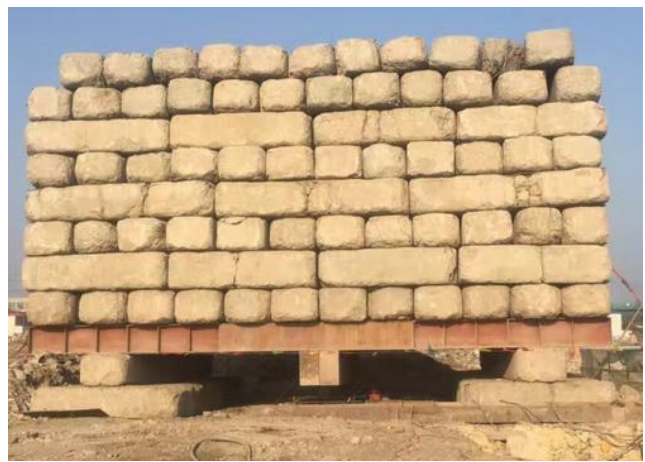

Figure 4: Static load test device

Pile shaft completeness was detected using acoustic transmission method according to relevant regulations [8]. ZBL-U520(A) non-metal supersonic test meter (Beijing Zhibolian Science \& Technology Co., Ltd., China) was used. As shown in Figure 5, two steel acoustic pipes $(\varphi 108 \mathrm{~mm} * 4 \mathrm{~mm})$ were embedded before construction of foundation piles, a measuring line was between 1 and 2 , and a measuring point was arranged every $10 \mathrm{~cm}$ on the measuring line.
A transducer was lifted from the pile bottom synchronously, and the detection covered the whole section, as shown in Figure 6. Due to the limited space, the unaccomplished matter and result evaluation criteria were not described here, and could refer to relevant regulations [8].

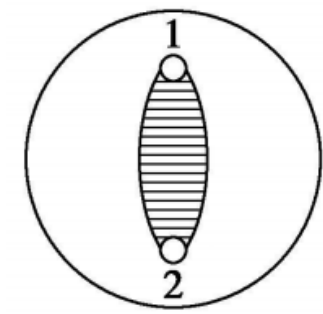

Figure 5: Layout of probe in piles

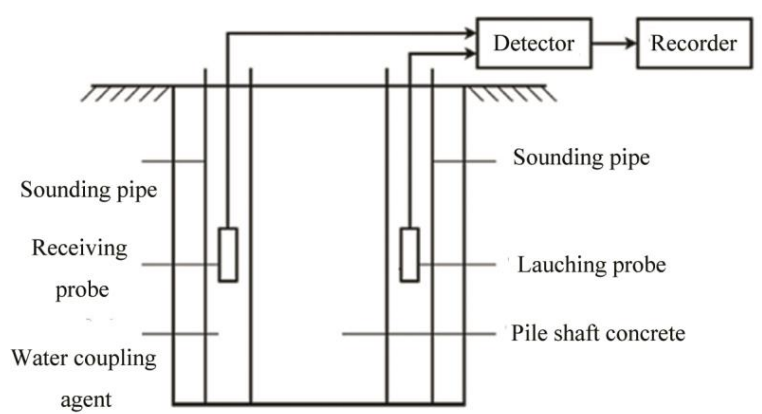

Figure 6: Schematic diagram of acoustic transmission method

\section{Analysis of Cast-in-Place Piles Test Results}

The results of the test piles constructed using five drilling schemes are shown in Table 3. The data shown in Table 3 were the average data of the test piles.

\begin{tabular}{|l|c|c|c|c|c|}
\hline \multicolumn{1}{|c|}{ Scheme } & $\begin{array}{l}\text { Rotary } \\
\text { excavating }\end{array}$ & $\begin{array}{l}\text { Replacement-filling } \\
\text { rotary excavating }\end{array}$ & $\begin{array}{l}\text { Churn } \\
\text { drilling }\end{array}$ & $\begin{array}{l}\text { Punching } \\
\text { method 1 }\end{array}$ & $\begin{array}{l}\text { Punching } \\
\text { method 2 }\end{array}$ \\
\hline Number of test piles & 2 & 3 & 3 & 3 & 3 \\
\hline $\begin{array}{l}\text { Total settlement of pile top } \\
(\mathrm{mm})\end{array}$ & & 20.25 & 18.76 & 19.20 & 10.93 \\
\hline Result of sounding & & Type I & Type I & Type I & Type I \\
\hline Filling coefficient & & 1.89 & 2.23 & 2.11 & 1.18 \\
\hline Construction period (h) & & 104 & 38.4 & 40 & 28.8 \\
\hline $\begin{array}{l}\text { Construction cost } \\
(10 \text { thousand yuan) }\end{array}$ & 5.3 & 5.5 & 5.2 & 7.8 \\
\hline Data discretization & & Large & Large & Moderate & Small \\
\hline In-situ requirements & Few & A few & Moderate & Moderate & Few \\
\hline Land occupation & Moderate & Large & Large & Moderate & Moderate \\
\hline Construction difficulties & Many & A few & A few & Moderate & Few \\
\hline
\end{tabular}

\subsection{Instruction of pile construction}

Two piles were constructed by means of rotary excavating. As to pile $1 \#$, the drilling speed of the drilling rig was quite slow, mud leakage was serious in the drilling process, the wall of hole collapsed when the hole had been $7 \sim 8 \mathrm{~m}$ deep, some stones fell into the hole, and finally the drilling rig was unable to work. As to pile $2 \#$, big rocks appeared when the hole was $3 \sim 4 \mathrm{~m}$ deep, and as a result the 
drilling rig was unable to work. Both piles failed; hence the test on pile 3\# was abandoned.

Piles $4 \# \sim 6 \#$ were all successfully constructed using replacement-filling rotary excavating. Pile 4\# and $5 \#$ were constructed in three days. The main problem in the construction of the two piles was the large difficulty in rotary excavating in the presence of gravels. As to pile 6\#, flowing plastic silt appeared when the silt layer was excavated. The surrounding silt constantly poured into the pile hole, and the hammer was locked because of the adhered silt. The ground tended to sink. All these conditions increased the difficulties of pile forming. Due to the additional steps including excavating rock-fill, refilling and tamping clay, the construction period of replacement-filling rotary excavating was longer than that of the other schemes.

Piles 7\# and 9\# were successfully constructed using churn drilling method. The main problem was that collapse happened in a small scope on the hole walls because of soil disturbance induced by the shifting of the two kinds of foundation pile construction machineries when it reached the siltrock-fill layer. In serve cases, many rocks from the walls of the hole fell into the hole, and the rotary drilling rig was unable to work. At that moment, percussion drill needed to be used. The conversion of the construction machineries would further disturb the soil layer and finally result in collapse of hole opening. Pile $8 \#$ failed because of that reason. Construction of pile foundation for a bank office building in the surrounding area adopted this scheme, and the waste pile rate exceeded $10 \%$. Different main parties held different opinions on the responsibility of the project, which even led to stoppage of construction. Drilling method lasted for about $8 \mathrm{~h}$, which was not beneficial to the fast promotion of the construction period.

Pile $10 \# \sim 12$ \# were all successfully formed using punching method 1 . The scheme effectively solved the problem of conversion of machineries caused $b$ falling of rocks. The major problem in the construction was that collapse might happen as rocks fell down under the cyclic action of impact load, and the impact load resulted in the flow of the silt layer. The problem also existed in the former two schemes.

Pile 13\# 15 \# were all successfully formed, and this scheme was the most successful. The major problem was that the casings were difficult to sink because of the large frictional force in a certain depth. The walls of the casing were $8 \mathrm{~mm}$; to prevent bending deflection, axial pressure could not be increased without consideration. Moreover the steel casings might deform severely under the effect of hoop pressure. The cost of the former schemes were close, about 53 thousand yuan, while the cost of this scheme was 78 thousand, which might contribute to the material and production cost of the steel casings which were $25 \mathrm{~m}$ long and $8 \mathrm{~mm}$ thick.
The pile forming quality and controllability of the scheme was obviously superior to those of the other schemes. The construction process data and detection data of the three test piles were basically the same, suggesting a small dispersion.

\subsection{Analysis of the filling coefficient}

The changes of the actual concrete placement volume of pile $4 \# \sim 15 \#$ with the changes of the pile position h are shown in Figure 7.

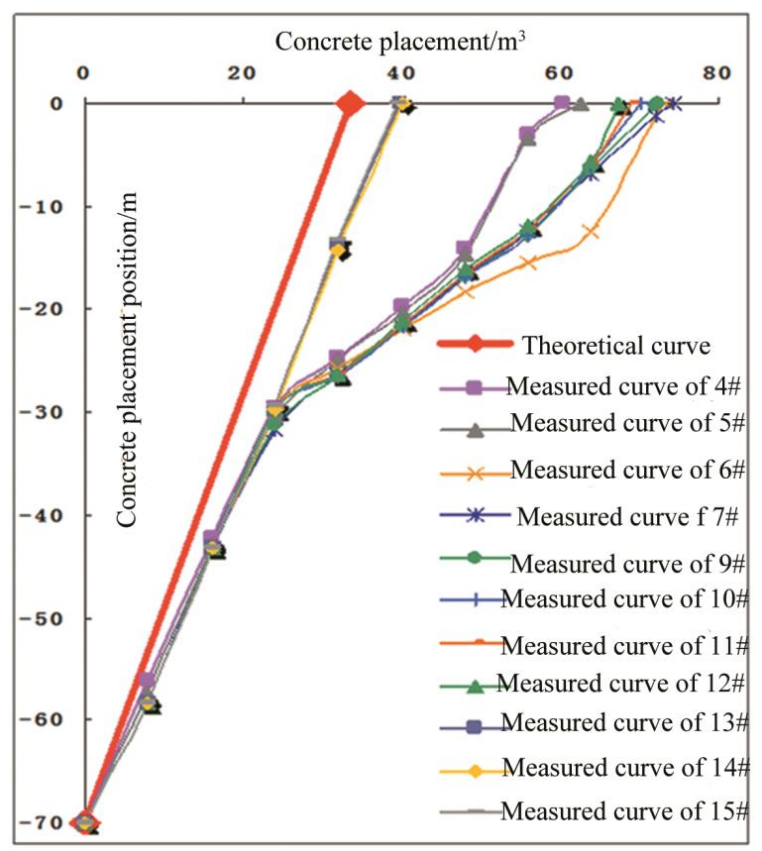

Figure 7: Concrete placement curve

As shown in Figure 7, the curves of concrete constructed using different construction methods were different, but the curves of concrete constructed using the same technique were basically consistent, indicating that every construction technique was basically stable.

The curves of piles constructed using the same technique under $30 \mathrm{~m}$ was basically consistent and differed slightly with the theoretical curves, and the value of project experience $c$ was between 1 and 1.25. The geographical survey report suggested that the region under $30 \mathrm{~m}$ was the clay layer, and the $\mathrm{c}$ value of the clay layer was about 1.15 [12]. It could be initially determined that no thin pile and deformed piles appeared in that region, and the control of engineering quality in that region was favourable. Some filling coefficients were close to 1.25 , and the value of $c$ was large, which was because of difficult drilling induced by the existence of siltrock fill layer in the upper part of the clay layer, local diameter expansion and inclination.

The geographical survey report suggested that the region above $30 \mathrm{~m}$ was where the silt-rock fill layer located. 
The values of $\mathrm{c}$ of the 11 piles differed significantly; the value of $c$ of pile $4 \# \sim 12 \#$ exceeded 2 , and some even reached 3.5.

The main reason was that the rock fill layer with many pores had severe leakage, drilling was difficult, local diameter expansion frequently happened, and concrete in local part of the silt layer which had a flowing state spread to the soil around the pile hole.

The value of $c$ of pile $13 \# \sim 15 \#$ was lower, about 1.05 , because that the steeling casing ensured fixed pore diameter and avoided outflow of concrete.

But the value was still larger than 1 , which was contributed to the waste caused by tight concrete vibration.

The values of $c$ of pile $4 \# \sim 6 \#$ was small above $12 \mathrm{~m}$, which was because that the rock fill layer in that region was replaced by the clay layer.

The value of c of pile $6 \#$ was obviously larger than that of pile $4 \#$ and $5 \#$.

The silt layer in the region where the pile $6 \#$ located had strong flow plasticity, which increased the difficulty of drilling, and a large amount of concrete spread to the surrounding area.

There was a sudden change of value of c of pile 13 \# 15 \# in the area at $30 \mathrm{~m}$. It was because that that region was the joint part of the silt layer and clay layer.

The steel casings entered shallowly into the clay layer, and the newly casted concrete penetrated the thin clay layer and spread to the silt layer.

Based on the above analysis, it could be concluded that the abnormal increase of the filling coefficient of concrete only happened in the silt-rock fill layer, and arrangement of steel casing during drilling could thoroughly solve the problem of abnormal filling coefficient.

\subsection{Analysis of load settlement rules}

The load settlement curves (Q-s curves) of the 11 test piles are shown in Figure 8.
Due to the limited space, only one representative S- lgt curve was represented.

Overall, the Q-S curves of piles whether steel casing was applied or not were smooth.

When the load was increased to $6200 \mathrm{kN}$, no obvious downward turning section was observed, neither the second inflection point; it was a typical slow change type curve, indicating that the cast-inplace piles in the silt-rock fill layer also suggested favorable mechanical properties.

When the load became the maximum, the maximum settlement volume S max of the top of the piles with and without steel casing was $10.87 \mathrm{~mm}$ and $19.49 \mathrm{~mm}$ respectively, both lower than $40 \mathrm{~mm}$, indicating that the bearing capacity of all the piles has not reached the limit.

The S max of three piles with steel casings was significantly smaller than the piles without steel casings, suggesting that the existence of steel casing increased the side friction of soil and affected the load-transferring mechanism.

After unloading, the maximum resilience value of the top of the piles with and without steel casings was $5.90 \mathrm{~mm}$ and $7.51 \mathrm{~mm}$ respectively, and the corresponding resilience rate was $38.5 \%$ and $54.3 \%$ respectively.

It revealed that the system of pile and soil was in an elastic range, and most of the settlement volume came from the compression of the pile shaft.

It could be seen that the curves were basically straight, the spacing between different curves showed a tendency of progressive increase, and the settlement of the pile top could be stable within 30 min under the action of different grades of load.

It could be seen from the Q-s curve and S-lgt curve that the vertical bearing capacity of the 11 test piles was all not lower than $3100 \mathrm{kN}$, i.e. the vertical bearing capacity achieved by the four schemes satisfied the design requirements.
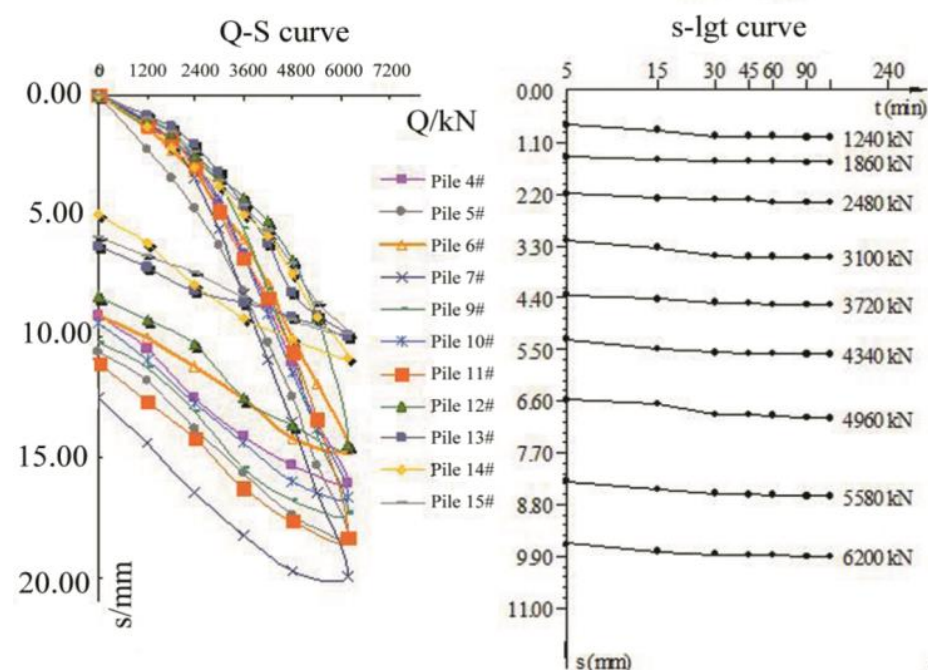

Figure 8: Static load results 


\subsection{Analysis of pile shaft completeness}

The results of the acoustic transmission test are shown in Table 4.

Due to the limited space, only the typical measured data curves are displayed (Figure 9).

The results demonstrated that the sound velocity $\mathrm{V}$ and amplitude $\mathrm{A}$ at every measuring point at different sections along the pile shaft were larger than the critical values, the acoustic parameters had no abnormalities, and the sound velocity at different sections where the measuring points located was larger than $3.8 \mathrm{~km} / \mathrm{s}$, suggesting that the concrete had favourable strength.

Moreover depth of measuring position-PSD (HPSD) curve had no sudden change, indicating that the concrete had normal quality.

The normal receiving waves suggested that the sediment at the bottom of the test piles had been eliminated thoroughly.

Based on the above analysis, the pile shaft completeness of all the piles could be determined as type I, and there were no type II, III and IV piles. The four cast-in-place pile construction schemes satisfied the design requirements in the aspect of pile shaft completeness.

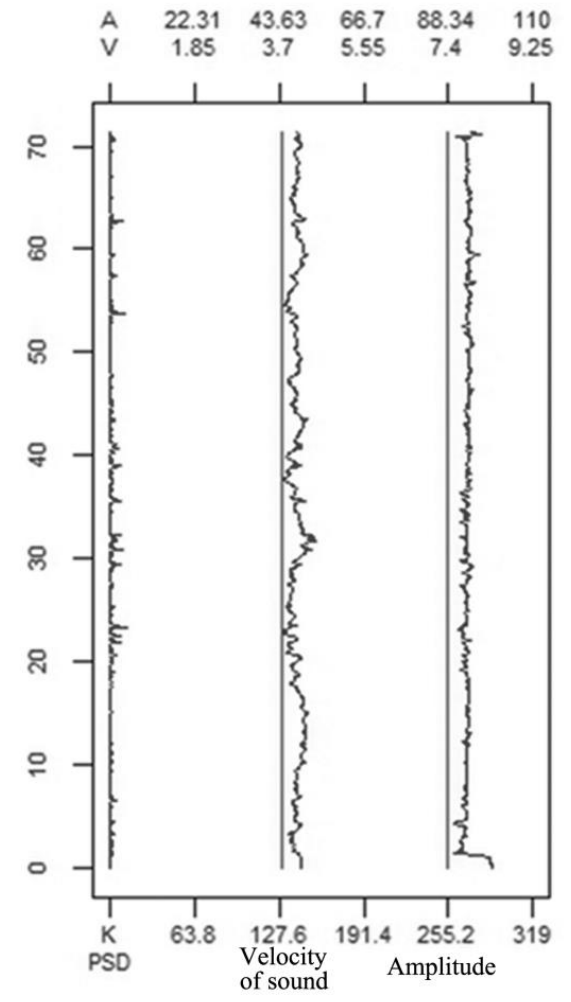

Figure 9: Typical measured curves

Table 4. Results of acoustic test

\begin{tabular}{|c|c|c|c|c|c|c|}
\hline $\begin{array}{c}\text { Construction } \\
\text { method }\end{array}$ & $\begin{array}{c}\text { Measured } \\
\text { depth } \\
(\mathrm{m})\end{array}$ & $\begin{array}{c}\text { Center } \\
\text { distance } \\
\text { of } \\
\text { acoustic } \\
\text { pipe } \\
\text { (mm) }\end{array}$ & $\begin{array}{c}\text { Average } \\
\text { value of } \\
\text { sound } \\
\text { velocity } \\
\text { (km/s) }\end{array}$ & $\begin{array}{c}\text { Average } \\
\text { value of } \\
\text { amplitude } \\
\text { (db) }\end{array}$ & $\begin{array}{c}\text { Critical value } \\
\text { of sound } \\
\text { velocity } \\
\text { (km/s) }\end{array}$ & $\begin{array}{c}\text { Critical value } \\
\text { of amplitude } \\
\text { (db) }\end{array}$ \\
\hline $\begin{array}{c}\text { Replacement } \\
\text { filling } \\
\text { method }\end{array}$ & 71.3 & 486 & 3.904 & 107.46 & 3.574 & 101.46 \\
\cline { 2 - 7 } & 72.2 & 485 & 3.973 & 106.89 & 3.588 & 100.89 \\
\hline \multirow{2}{*}{$\begin{array}{c}\text { Churn } \\
\text { drilling }\end{array}$} & 71.5 & 480 & 4.027 & 107.09 & 3.654 & 101.09 \\
\hline \multirow{2}{*}{$\begin{array}{c}\text { Punching } \\
\text { method 1 }\end{array}$} & 71.0 & 490 & 4.110 & 107.04 & 3.645 & 101.04 \\
\cline { 2 - 7 } & 70.2 & 480 & 4.187 & 107.33 & 3.420 & 101.33 \\
\hline \multirow{2}{*}{$\begin{array}{c}\text { Punching } \\
\text { method 2 }\end{array}$} & 73.5 & 478 & 4.023 & 107.03 & 3.685 & 101.03 \\
\cline { 2 - 7 } & 71.8 & 480 & 4.167 & 106.56 & 3.757 & 100.56 \\
\cline { 2 - 7 } & 71.0 & 480 & 4.023 & 106.54 & 3.560 & 99.99 \\
\hline
\end{tabular}

\section{Conclusion of the Test Piles}

Based on the above analysis, it could be seen that rotary excavating method was not suitable as it could not penetrate the rock fill layer. But the other four schemes could satisfy relevant regulations and design requirements, affirming the effectiveness of them as the construction schemes of pile foundation in silt-rock fill layer.

The field machinery operation of replacementfilling rotary excavating method and churn drilling method was two times that of punching; the increased disturbance to the silt-rock fill layer increased the risks of pile hole collapse and flow in silt layer. Moreover both methods needed large sites, which was not beneficial to engineering progress and moreover increased the difficulty of construction in late stage. Neither of the two techniques could provide an effective solution to difficult drilling in the silt-rock fill layer. Therefore we considered that the two construction methods could not be regarded as the major technique, but could be alternatives in local areas.

Punching scheme was optimal. The construction control was ideal when soil had relatively good properties. Punching method 1 was acceptable in 
aspects of construction period and cost. Punching method 2 could also achieve a successful result. Once drilling became difficult, slurry was replaced by steel casings to protect walls.

Punching method 2 was considered optimal in the aspect of pile forming. But the application of steel casings increased the cost. We will discuss the optimal of steel casing length through full-scale test in the next scale.

\section{Optimal Test For Length of Steel Casing}

\subsection{Design of test}

Twenty-one piles were tested in the same site using punching scheme. The technical parameters of the pile foundation were consistent with those of engineering piles. There were 7 buried depths of the steel casings, as shown in Figure 10. Each depth was tested using three piles. The steel casings were $8 \mathrm{~mm}$ thick. Position 0 stood for absence of steeling casing; data used were the test results of punching scheme 1.
The data used at position 4 were the test results of punching scheme 2. The depth and thickness of soil at the other five positions are shown in Table 5.

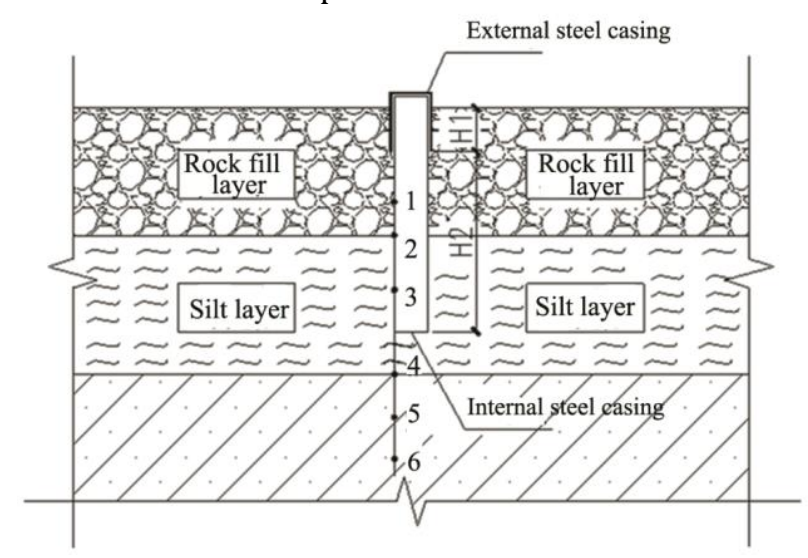

Figure 10: Schematic diagram of steel casting

\subsection{Test results}

The average data obtained in the test are shown in Table 5. The units for time, length and cost were hour, $\mathrm{m}$ and ten thousand yuan respectively.

\begin{tabular}{|l|c|c|c|c|c|c|}
\hline Position & $\begin{array}{c}\text { Thickness of } \\
\text { rock fill }\end{array}$ & $\begin{array}{c}\text { Thickness of } \\
\text { silt }\end{array}$ & $\begin{array}{c}\text { Length of } \\
\text { casing }\end{array}$ & $\begin{array}{c}\text { Constructio } \\
\text { n period }\end{array}$ & $\begin{array}{c}\text { Filling } \\
\text { coefficient }\end{array}$ & Cost \\
\hline 0 & 10.3 & 17.7 & 0 & 40 & 2.82 & 5.2 \\
\hline 1 & 10.5 & 17.9 & 8 & 36 & 2.64 & 6.4 \\
\hline 2 & 10.2 & 17.4 & 10 & 35.8 & 2.56 & 6.7 \\
\hline 3 & 9.8 & 17.1 & 16 & 30.2 & 2.06 & 7.5 \\
\hline 4 & 10.2 & 17.7 & 24 & 28.8 & 1.18 & 7.8 \\
\hline 5 & 10.3 & 17.8 & 26 & 27.4 & 1.15 & 8.1 \\
\hline 6 & 10.7 & 18.1 & 30 & 27.4 & 1.15 & 8.7 \\
\hline
\end{tabular}

With the increase of the length of steel casings, the construction period gradually shortened. It was because that the impact speed was higher and the concrete placement volume reduced due to the higher stability and reliability of the steel casings. When the steel casings were buried at position 4,5 and 6 , the influence on the construction period was little. It was because that drilling became easy after entering the clay layer.

The existence of steel casings reduces labour cost. $45 \mathrm{t}$ of concrete can be saved to the maximum; if one ton of concrete cost 400 yuan, then 20,000 yuan could be saved. But steel casing per meter cost 14 , 500 yuan, and a steel casing which is $30 \mathrm{~m}$ long will cost 45,000 yuan. When the steel casing was buried at position 5 or 6 , the filling coefficient kept stable, and the saving volume of concrete reduced. Increasing the length of steel casings could accelerate the increase speed of cost.

In the aspects of construction period, cost and filling coefficient, it could be seen that it was not necessary to burry steel casings at position 2 or the position below position 5 .
When the construction condition was good and engineering budget was small, then the application of steel casings could be avoided. When the construction period was short and engineering budge was enough, position 4 was the best.

If the volume of concrete was reduced for the sake of environmental protection, position 5 could be selected.

\section{Construction Summary and Engineering Effect of Pile Foundation}

All the 3867 cast-in-place piles have been constructed according to the design and construction contract in March 2016.

The drilling scheme followed the above research achievements. Steel casings were used only when drilling became difficult. Totally 1024 steel casings were used; the average filling coefficient was 1.34, the average construction period was 2.01 days, the average buried depth was $15 \mathrm{~m}$, and the average cost was 8,000 yuan more than that of piles without steel casings. 
The average filling coefficient of the piles with steel casings was 1.92 , and the average construction period was 2.56 days.

According to the design requirements, 102 piles were randomly selected for vertical compressive static load test, 403 piles were selected for pile shaft completeness test using acoustic transmission method, and the shaft completeness of all the piles was tested using low strain method.

The results suggested that the bearing capacity satisfied the design requirements; all the piles were determined as type I in the acoustic test; 3759 piles were determined as type I in the dynamic test (97.2\%), and the remaining 108 piles were determined as type II because of the existence of light defects at the upper part; there were no type III and IV piles. $83.2 \%$ of the piles had a deviation of pile position within $50 \mathrm{~mm}$, and the maximum deviation was below $85 \mathrm{~mm}$, conforming to the requirement on deviation.

\section{Conclusions}

Cast-in-place piles can be applied in pile foundation engineering in areas with silt-rock fill soil. Rotary excavating method, replacement-filling rotary excavating method and churn drilling method are not suitable for drilling of cast-in-place piles in siltrock fill layer, and punching is the best scheme. When punching method is used for drilling, the application of steel casings can effectively avoid problems of collapse of the rock fill layer, flow of the silt layer and excessively large filling coefficient.

The application of steel casings is beneficial to the improvement of compressive bearing capacity of pile foundation, and the relevant mechanical mechanism remains to be further investigated. Considering the high cost of steel casings, the buried depth should be determined based on construction period, cost and environmental protection. When the buried depth is $2 \mathrm{~m}$ deeper than the bottom of the silt layer, the optimization for construction period and filling coefficient will be limited. It is not optimal to make the buried depth of steel casings at the same level of the bottom of the rock fill layer.

The above conclusions have been applied in the construction of 3867 engineering piles successfully.

Testing via construction practice is of realistic guiding significance to the similar engineering practices and subsequent project construction.

\section{Acknowledgement}

This study was supported by Youth Fund Project of National Natural Science Foundation of China (No. 51508071) and the Key Subject Research of Wenzhou Vocational \& Technical College (No. wzy2016003).

\section{References}

[1] Fanny D. "The importance of marine spatial planning in advancing ecosystem-based sea use management," Marine Policy, 2008, 32 (5): 762 771

[2] "The Ministry of Construction of the People's Republic of China," JGJ 94-2008 Technical code for building pile foundation. Beijing: China Architecture and Building Press, 2008.

[3] Zhao W, Wu X J. "Application of rotary drilling bored grouting pile in complicated formation of coastal areas (Shenzhen)," Chinese Journal of Geotechnical Engineering, 2013, 10:1196-1199.

[4] Lei B, Xia H L. "Supporting construction technology of long steel casing, percussion and grabbing and rotary drilling bored pile in siltrock fill layer," Chinese Journal of Geotechnical Engineering, 2013,10:1184-1187.

[5] Donald E G, Mark J. "Wahler and Jose L.M. Clemente. Bored Cast-In-Place Conerete Piling for an Aluminum Smelter Port Facility," The Art of Foundation Engineering Practice Congress, 2010.

[6] Xu H C, Tang Z W, Xiong Q. "Drilling technique inlarge boulder formation," World Geology, 2000, 19(3): 307-312.

[7] Liu S N, Zhu Y G. "Problems and countermeasures of hammerblocking in construction of pouring rock-socketed piles," Port \& Waterway Engineering, 2011(2):137$139,148$.

[8] "The Ministry of Construction of the People's Republic of China," JGJ 106-2003 Technical code for testing of building foundation piles. Beijing: China Architecture and Building Press, 2003.

[9] Zhang X W, Guan Y J, Zhou J H. “Application of PHP slurry to drilling of over-length and extralarge diameter bored-piles," Chinese Journal of Rock Mechanics and Engineering, 2005, 24(14): 2571-2575.

[10] Zomora M, Bleier R. "Prediction of drilling mud rheology using a simplified Herschel-Bulkley mode," Journal of Pressure Vessel Technology, 1997, 99(3): 485-490.

[11] Li Z, He X C, Wang Y F. "Construction Technology of Bored Piles in Plastic Soft Soil of Stockmann Nevsky Center," Construction Technology 2010, 39(1): 22-24, 32.

[12] Shi P D. "Pile and pile foundation handbook," Beijing: China Communications Press, 2008. 